\title{
Antioxidant effect of Iloprost: current knowledge and therapeutic implications for systemic sclerosis"
}

\author{
Effetto antiossidante dell'Iloprost: stato dell'arte e implicazioni \\ per la terapia della sclerosi sistemica
}

\author{
G.L. Erre, G. Passiu \\ Cattedra e Scuola di Specializzazione di Reumatologia, Università degli Studi di Sassari, Sassari
}

\begin{abstract}
RIASSUNTO
Il ruolo dello stress ossidativo come minimo comune denominatore dei tre principali momenti patogenetici della sclerosi sistemica (SSc) -attivazione dell'immunità cellulare e umorale, danno microvascolare e diffusa fibrosi tissutale è sottolineato da una lunga serie di evidenze scientifiche. Pertanto provvedimenti terapeutici mirati a ridurre lo stress ossidativo potrebbero avere un effetto favorevole sulla severità delle manifestazioni cliniche e sulla progressione della malattia. L'Iloprost, analogo sintetico della prostaciclina $I_{2}$, impiegato per il trattamento delle manifestazioni vascolari della SSc, possiede, oltre ai noti effetti vasodilatante e antiaggregante, anche un'attività antiossidante. Questa breve rassegna ha lo scopo di discutere le principali evidenze scientifiche che supportano l'azione antiossidante dell'Iloprost e le vie molecolari che la sottendono.
\end{abstract}

Reumatismo, 2009; 61(2):90-97

\section{INTRODUCTION}

S ystemic sclerosis ( $\mathrm{SSc}$ ) is a dysimmune disorder of connective tissue characterized by disregulation of endothelial function and progressive tissue fibrosis. Although many studies have been carried out the pathogenesis of SSc is an issue still elusive. In a pioneer paper Murrel DF suggested oxidative stress (OS) as the keystone linking altered immune tolerance, endothelial injury and pro-fibrotic phenotype of SSc (1). In the last decade, this intriguing hypothesis has been strengthened by several firm evidences obtained at a cellular and molecular level.

OS refers to a condition characterized by an imbalance in prooxidants and antioxidants, which results in damage to macromolecules (protein, lipids

*Lavoro premiato al XLV Congresso SIR, Venezia 2008.

\footnotetext{
Indirizzo per la corrispondenza:

Dott. Gian Luca Erre

Chair of Rheumatology

University of Sassari

V.le San Pietro, 8

07100 Sassari, Italy

E-mail: e.gianluca@libero.it
}

and DNA) and disruption of the redox network (2). Prooxidant injury is due to oxygen-derived small molecules called reactive oxygen species (ROS). These include both free radicals [superoxide anion $\left(\mathrm{O}_{2}^{--}\right)$, nitric oxide $\left(\mathrm{NO}^{\circ}\right)$ and hydroxyl radical $\left(\mathrm{OH}^{\circ}\right)$ ] and non radical oxidants [hydrogen peroxide $\left(\mathrm{H}_{2} \mathrm{O}_{2}\right)$, peroxinitrite $\left(\mathrm{ONOO}^{-}\right)$and aldehydes (e.g malondialdehyde, MDA)] (Fig. 1). Free radicals are quickly converted into reactive non radical oxidants which in turn give rise in a vicious loop to other free radicals.

Deleterious effects of OS are physiologically blunted by antioxidant systems, including free radical scavenging enzymes [superoxide dismutase (SOD), catalase (CAT)] and abundant radical-scavenging chemicals, such as vitamin $\mathrm{E}$ and $\mathrm{C}$. Also glutathione (GSH) is involved in antioxidant system. Its oxidized form is a dimmer (GSSG) which act as a coenzyme and protects against ROS and other toxic compounds. OS has been reported to be increased in SSc $(3,4)$ and variously associated to Raynaud's phenomenon (5), $\mathrm{Th}_{2}$-shifting of T cells (6), autoantibodies production (7), endothelial apoptosis (8) and pro-fibrotic genes expression (9). Moreover, also the scavenging systems seem im- 


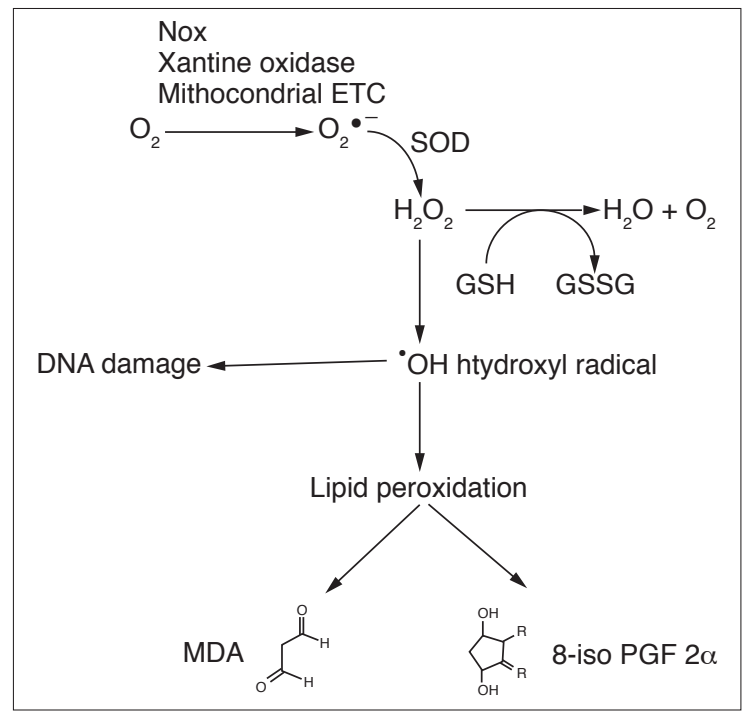

Figure 1 - ROS formation pathway. ETC, electron chain transport.

paired in SSc patients consistently with the evidence of reduced reserve of ascorbic acid, selenium (5), $\alpha$-tocopherol and carotene (10) regardless of appropriate dietary intake (11).

Therefore targeting OS may have a favorable impact on the clinical features and progression of SSc. Intriguingly, two drugs effective in the treatment of some clinical SSc features such as calcium channel blockers and ACE-inhibitors possess an interesting activity in reducing OS due to inhibitory effect on the activity of ROS producing enzymes $(12,13)$. Unfortunately, interventional trials with antioxidant agents designed to reduce OS in SSc have given conflicting and disappointing results (14-17). Iloprost, a stable prostacyclin-mimetic drug, is widely prescribed to treat vascular features of SSc (Raynaud's phenomenon, digitals ulcers and pulmonary arterial hypertension) on the grounds of its well known vasodilatory and antiaggregant effects. Beside these actions, Iloprost appears to have also an antioxidant effect which substantially adds on to the spectrum of his "non conventional" (e.g. antifibrotic and angiogenetic) actions.

Yet molecular pathways underlying this putative property have been not fully dissected, nonetheless several reports offer the clues to suggest them.

\section{NADPH Oxidase (Nox) and MAPK pathways in SSc}

ROS are physiological "inescapable" byproduct of cellular metabolism and derive from multiple cellular sources, including mitochondrial electron transport and xanthine oxidase. In most of cellular types the largest amount of ROS is generated by Nox, a heme-containing multi-subunit enzyme which catalyze the production of $\mathrm{O}_{2}{ }^{--}$(which plays a role in phagocitic cells against infections owing to its bactericidal activity).

Nox consists of the membrane bound cytochrome b558 (p22 $2^{\text {phox }}$ and the enzymatic subunit gp91 ${ }^{\text {phox }}$ ), several cytosolic proteins ( $\mathrm{p} 47^{\mathrm{phox}}$ and $\mathrm{p} 67^{\mathrm{phox}}$ ), and a GTP-binding Rac protein. Nox exerts its activity once phosphorylated cytosolic subunits and Rac are translocated to the membrane and complexed with cytochrome b558 (18).

Under physiological conditions several stimuli [e.g hypoxia (19), proinflammatory cytokines (20), growth factors (21), angiotensin II, (22) and $\mathrm{O}_{2}^{-{ }^{-}}$itself (23)] are proven to up-regulate Nox through different pathways, including subunits (24) and Rac (25) activation. Curiously, each of these factors seems directly involved in the development of SSc. Upon stimulation Nox generates $\mathrm{O}_{2}^{-{ }^{-}}$and $\mathrm{H}_{2} \mathrm{O}_{2}$ which in turn act as second messengers activating several signalling pathways involved in cell growth regulation and differentiation. Thus, for example, growth factors as PDGF and TGF- $\beta$ interacting with the tyrosine kinases receptor (TKRs) enhance Nox activity via Ras signaling (26). Once generated, ROS transduce the proliferative and fibrotic signals of PDGF and TGF- $\beta$ by turning on the mitogen activated kinases (MAPK) cascade. Member of this latter family are extracellular signal-regulated kinases 1 and 2 (ERK1/2), Jun NH2-terminal kinase (JNK) and p38 kinase. Thus the proper transmission of growth signal rely on the action of ROS as signalling factors. Indeed, at low concentration the integrity of ROS production is essential for regulation of important cellular features, while aberrant and unregulated ROS accumulation may lead to pathologic permanent change in signal transduction.

At this regard, interestingly, monocytes from patients with SSc constitutively release large amounts of $\mathrm{O}_{2}{ }^{--}$and $\mathrm{H}_{2} \mathrm{O}_{2}$ in vitro through the Nox pathway (27). In particular in SSc fibroblasts has been demonstrated the persistent activation of intracellular Ha-Ras/ERK1-2/Nox loop (28, 29).

But, if this is so, which factors are able to trigger and maintain the machinery involved in ROS generation in SSc? In an elegant study has been provided the evidence that sera of SSc patients invariably show stimulatory antibodies to PDGF receptor. The interaction ligand-receptor at the cellular surface turn on the Ras/Nox/ERK1-2 pathway which lead to pro-fibrotic gene expression (3) (Fig. 2). 


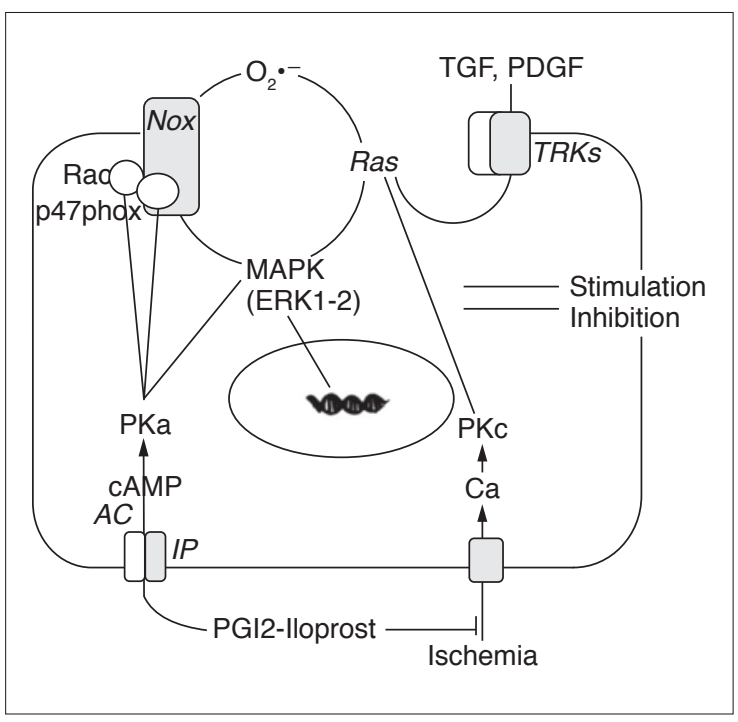

Figure 2 - Putative pathways of antioxidant activity of Iloprost. AC, adenylate cyclase; cAMP, cyclic adenosine monophosphate; Pka, protein kinase A; Pkc, protein kinase C; TRKs, tyrosine kinase receptor.

Taken collectively these data help to clarify the pathogenic puzzle of SSc, highlighting the hypothesis that OS may be the missing link between humoral immunity activation and fibrotic process.

\section{Asymmetric dimethylarginine (ADMA) and $O S$ in $S S c$}

Several reports have recently pointed out the role of (ADMA), an endogenous inhibitor of nitric oxide synthase, in promoting endothelial dysfunction (30).

An increase of plasma ADMA levels has been reported in patients affected by SSc (31) and it has been supposed that ADMA would affect arteriolar tone by reducing nitric oxide (NO) availability. Moreover, has been demonstrated a significant association between raised ADMA levels and increased endothelial permeability (32), impaired progenitor endothelial cells reserve (33) and defective angiogenesis (34), all of them are critical steps in the development and progression of SSc. Very recently in an experimental model has also been proven that exogenous ADMA elicits vascular diameter reduction by increasing Nox-related ROS production (35). Moreover, ROS accumulation seems to promote ADMA elevation reducing the activity of the ADMA demethylating enzyme physiologically involved in its catabolism (36).

Furthermore, a convincing proof of the redox sensitive regulation of ADMA metabolism comes from the observation that antioxidant treatment is able to reduce plasma ADMA levels (37).

In synthesis, the interrelation between ADMA/NO pathway and ROS production is well accepted. Therefore it is conceivable that an increase of OS would be the link between ADMA elevation and endothelial dysfunction in SSc.

\section{Isoprostanes and $S S c$}

Lipid peroxidation occurs as a part of the oxidant injury, involves several substrates and leads to highly reactive intermediates formation (Fig. 1). Among them are isoprostanes, a family of eicosanoids produced predominantly by free radical oxidation of arachidonic acid esterified to phospholipids (38) (Fig. 1).

Therefore, determination of $\mathrm{F}_{2}$-isoprostanes levels (in particular of 8-iso $\mathrm{PGF}_{2}$ ) is currently considered one of the best available tool to assess OS level in vivo (39).

Moreover, isoprostanes are more than inert markers of oxidative burden: they are proven to induce ROS production (40), to mediate vascular constriction $(41,42)$, endothelin-1 gene expression (43) and fibroblast proliferation (44) and to impair angiogenesis (45), all of them are well known specific features of SSc.

Thus, is not surprising that raised isoprostanes levels have been demonstrated in different organic fluids (46-50) in SSc and are related to severity and extent of visceral (49) and vascular involvement $(49,51)$. Of interest such an increase of $\mathrm{F}_{2}$-isoprostanes seems predominate in the early steps of SSc (50) highlighting the role of OS as a key factor in the induction of disease.

\section{Clinical and experimental evidences of antioxidative effect of Iloprost}

If we look back to the field of prostacyclin and oxidative stress we find several clinical and experimental data about the potential role of Iloprost both in reducing ROS amount and in strength scavenger system efficiency.

In two seminal papers a reversible and dose-related inhibition of the $\mathrm{O}_{2}{ }_{2}^{-}$production (by neutrophils) was demonstrated in animal models of ischemic myocardium damage in the presence of Iloprost $(52,53)$. In addition, Iloprost has proven to significantly decrease MDA in animal models of abdominal aortic ischemia-reperfusion (54) and induced liver peroxidation (55) and to reduce $\mathrm{H}_{2} \mathrm{O}_{2}$ induced pathological glaucomatous changes in cultured cells (56). Similarly Iloprost infusions in vi- 
vo appeared to significantly reduce levels of MDA in patients affected by SSc (57).

Being isoprostanes markers and mediators of OS burden in SSc, evidence of Iloprost ability in reducing their levels would offer a substantial proof about the genuineness of its antioxidant effect. Unfortunately, the results of a study ad hoc designed to evaluate this issue in the setting of SSc are disappointing (58).

We very recently evaluated in an open label prospective study the acute effect of Iloprost on urinary 8-isoPGF ${ }_{2 \alpha}$ levels in SSc patients (59). Urinary 8 -isoPGF ${ }_{2 \alpha}$ levels were measured before and after a five days infusional cycle of iloprost (0.5-2 $\mathrm{ng} / \mathrm{kg} / \mathrm{min}$, mean dose $1.3 \mathrm{ng} / \mathrm{kg} / \mathrm{min}$ ) in twenty eight SSc patients. Post-infusional urinary 8isoPGF $F_{2 \alpha}$ levels appeared significantly reduced respect to basal levels in SSc patients but they remained elevated compared to control subjects. Of interest from a clinical point of view, a more significant decline in 8-isoPGF ${ }_{2 \alpha}$ levels was demonstrated in the early phases (disease duration $<5$ yrs) and in the limited subset of disease suggesting that the antioxidant activity of Iloprost is most likely to be effective early in the course of SSc. This finding may be of considerable interest since it would also help to explain the failure of antioxidant therapy in clinical trials in SSc, suggesting that the treatment was administered too late in the course of disease.

The results of our study agree well with earlier report which show a reduction of isoprostanes in patients with primary pulmonary arterial hypertension receiving epoprostenol, a synthetic salt of prostacyclin (60).

Iloprost activity in preserving scavenging system has also reported to positively affect hearth transplantation in an animal model when added to cardioplegic solutions, by maintaining levels of GSH and CAT in transplanted organ (61). Similarly pretreatment of isolated hearts with Iloprost improved myocardial GSH/GSSG ratio and SOD levels in ischemia-reperfusion injury (62) and myocardial infarction $(63,64)$.

Iloprost potential in restoring antioxidant reserve (CAT and SOD levels) was also provided in vivo, in patients affected by SSc: the authors also propose that this effect on inner antioxidant capacity can explain the long-term effect of Iloprost instead of its very short half-life time (57).

A reduction of ADMA level, and by inference, of OS is expected to have therapeutic implications in vascular disease. Very recently Iloprost has shown to reduce ADMA levels in patients with Büerger disease (65).

On the basis of the above reported tight correlation between ADMA and OS, this observation would support that Iloprost antioxidant properties might be the indirect consequence of a beneficial regulation of ADMA/NO pathway.

Taken together these findings support the assumption that treatment with prostacyclin analogs in vivo would carry a singular and clinically meaningful effect in balancing OS.

\section{Putative pathways of OS reduction by Iloprost}

Despite the fact that a substantial amount of literature is available on the antioxidant effect of Iloprost, the mechanisms behind it are less clear.

Prostanoids are derivative of arachidonic acid and they possess multiple and even opposing effects, the most known being the regulation of vascular homeostasis.

Among these compounds TXA ${ }_{2}$ induces vasoconstriction and platelet aggregation, while prostacyclin $\left(\mathrm{PGI}_{2}\right)$ is a potent vasodilator and antiaggregant agent. $\mathrm{PGI}_{2}$ signals through a single G-protein-coupled receptor (IP) (66), increasing intracellular cAMP in several cellular types. Iloprost is a long lasting synthetic analog of $\mathrm{PGI}_{2}$ of which it mimics physiologic activities interacting with the prostacyclin (IP) receptor (67).

One of the most consistent features of scleroderma is the excessive vasoconstriction in response to stimuli, such as cold exposure, often followed by excessive reactive hyperaemia on rewarming. Such an condition, termed Raynaud's phenomenon, leads to harmful ischemia-reperfusion injury, obviously in peripheral tissue but also in internal organs.

A significant burst of ROS generation in this hypoxic milieu occurs as a consequence of adenosine triphosphate depletion. This latter event is rapidly followed by different calcium channels opening and increase of cytosolic $\mathrm{Ca}^{2+}$ which in turn enhances the PKc/RAS/Nox pathway (Fig. 2) (68).

In addition, as previously stated, hypoxia powerfully upregulates Nox expression contributing to ROS generation. Therefore, the reduction of vasospastic propensity gained with Iloprost infusions would indirectly lower intracellular ROS accumulation via both the reduction of cytosolic $\mathrm{Ca}^{2+}$ overload and the tyrosin kinases receptor MAPK pathway inhibition. In support of this mechanism, treatment with prostacyclin analogues of cultured rat hepatocytes exposed to superoxide demonstrated cytoprotection via an increase in intracellular 
cAMP and a decrease in free intracellular calcium levels (69).

Alternatively, has been showed that an improvement in perfusion would be exert a beneficial effect on the level of antioxidant system and a reduction in free catalyzed lipid peroxidation (57).

Nonetheless it is known that OS is a chronic condition in SSc depending just in a minimal manner from transient vasospastic attack (70). Moreover, the major question whether ROS generation is an upstream signal respect to hypoxic injury or conversely its consequence has not clearly solved so far (71).

Considering these pros and cons the "anti-ischemic" effect of Iloprost is unlikely to greatly account for the stable reduction of "oxidant assaults". More interestingly, as above stated, the machinery accounting for ROS production appears constitutively activated in $\mathrm{SSc}$ fibroblasts regardless from physiologic stimulation $(3,28)$ and may be the main source of OS in SSc. Thus disruption of vicious circuitry leading to Nox activation may have the potential to reduce OS and minimize its deleterious effect in activating proliferative and profibrotic signals.

At this regard, Muzzafar et al. provided a series of unequivocal evidences that Iloprost is able to reduce the activity and expression of NOX in vascular cells: the Rac and p47phox activation and translocation to the plasma membrane, an essential step for Nox functionality, appear inhibited in vitro by cAMP-protein-kinase-A (PKA) axis after incubation with Iloprost $(24,72,73)$.

Similarly has been clearly demonstrated in an in vitro model that Iloprost reduce profibrotic effect of PDGF by inhibiting the Ras/ERK1-2 pathway trough the cAMP-protein-kinase-A (PKa) axis. In particular was proven that Iloprost is able to inhibit ERK phosphorilation and that this effect can be abolished by PKa inhibitor. (74, 75) (Fig. 2).
Therefore, trough suppression of Nox expression and subsequent ROS accumulation, Iloprost would directly reduce OS related tissue damage and profibrotic intracellular signalling.

These observations further support the hypothesis that OS is deeply implicated in the induction of profibrotic phenotype of SS.

\section{CONCLUDING REMARKS}

OS is linked to SSc in a fashion so intricate that at present the question whether it is a culprit or a downstream consequence of vasculopathy and tissue injury is far to be convincingly answered.

Nonetheless, there are little doubts that OS is primarily and early involved in the pathogenesis of disease suggesting that targeting OS may potentially reduce the severity of clinical features.

However, despite the efforts yet the most compelling evidence of this assumption (inhibition/reduction of tissue injury by antioxidant therapy) has not been clearly provided.

At this regard, it would be of interest for the management of SSc to obtain more convincing proof about the antioxidant activity of Iloprost and to clarify the dimension of its relative contribution to the beneficial effects of this therapy.

Thus, further trials that will be performed to evaluate this issue should be specifically aimed to explore the following points:

I. confirm in vivo the effect of Iloprost on OS and quantify the clinical benefits in terms of tissue damage and prognostic impact.

II. evaluate the presence of a medium/long-term effect, beyond the brief space of the infusional cycle.

III. further clarify the potentially involved molecular pathways

\section{SUMMARY \\ Many lines of independent research have pointed out the role of oxidative stress as a fascinating pathogenic link be- tween the three main hallmarks of systemic sclerosis (SSc), viz. humoral and cellular immunity activation, microvas- cular damage and widespread tissue fibrosis. Therefore counteracting oxidative stress may have a favorable impact on clinical features and progression of disease. It is becoming clearer that Iloprost, a synthetic stable analogue of prosta- cycline, currently employed in the treatment of SSc vascular features, also possess anti-oxidative properties beside its prostaglandin-like vasodilatory and antiaggregant effects. This brief review is aimed to discuss available clinical evi- dences supporting Iloprost antioxidant action and focus on putative molecular pathways underlying it.}

Parole chiave - Iloprost, oxidative stress, systemic sclerosis, isoprostanes, NADPH oxidase.

Key words - Iloprost, stress ossidativo, sclerosi sistemica, isoprostani, NADPH ossidasi. 


\section{REFERENCES}

1. Murrell DF. A radical proposal for the pathogenesis of scleroderma. J Am Acad Dermatol 1993; 28: 78-85.

2. Sies H, Jones DP. Oxidative stress. In: Encyclopedia of stress (2nd ed.), edited by Fink G: Elsevier 2007; 45-8.

3. Baroni SS, Santillo M, Bevilacqua F, Luchetti M, Spadoni T, Mancini M, et al. Stimulatory autoantibodies to the PDGF receptor in systemic sclerosis. N Engl J Med 2006; 354: 2667-76.

4. Tikly M, Channa K, Theodorou P, Gulumian M. Lipid peroxidation and trace elements in systemic sclerosis. Clin Rheumatol 2006; 25: 320-4.

5. Herrick AL, Rieley F, Schofield D, Hollis S, Braganza JM, Jayson MIV. Micronutrient antioxidant status in patients with primary raynaud's phenomenon and systemic sclerosis. J Rheumatol 1992; 21: 1477-83.

6. King MR, Ismail AS, Davis LS, Karp DR. Oxidative stress promotes polarization of human $\mathrm{T}$ cell differentiation toward a T helper 2 phenotype. J Immunol 2006; 176: 2765-72

7. Casciola-Rosen L, Wigley F, Rosen. A Scleroderma autoantigens are uniquely fragmented by metal-catalyzed oxidation reactions: implication for pathogenesis. J Exp Med 1997; 185: 71-9.

8. Sgonc R, Gruschwitz MS, Dietrich H, Recheis H, Gershwin ME, Wick G. Endothelial cell apoptosis is a primary pathogenetic event underlying skin lesions in avian and human scleroderma. J Clin Invest 1996; 98: 785-92.

9. Falanga V, Martin TA, Takagi H, Kirsner RS, Helfman $\mathrm{T}$, Pardes J, et al. Low oxygen tension increases $\mathrm{mR}$ NA levels of alpha 1(I) procollagen in human dermal fibroblasts. J Cell Physiol 1993; 157: 408-12.

10. Lundberg AC, Akesson A, Akesson B. Dietary intake and nutritional status in patients with systemic sclerosis. Ann Rheum Dis 1992; 51: 1143-8.

11. Herrick AL, Worthington H, Rieley F, Clarke D, Schofield D, Braganza JM, Jayson MI. Dietary intake of micronutrient antioxidants in relation to blood levels in patients with systemic sclerosis. J Rheumatol 1996; 23: 650-3.

12. Allanore Y, Borderie D, Périanin A, Lemaréchal H, Ekindjian OG, Kahan A. Nifedipine protects against overproduction of superoxide anion by monocytes from patients with systemic sclerosis. Arthritis Res Ther 2005; 7: R93-100.

13. Münzel T, Keaney Jr JF. Are ACE inhibitors a "magic bullet"against oxidative stress? Circulation 2001; 104: 1571-4.

14. Mavrikakis ME, Lekakis JP, Papamichael CM, Stamatelopoulos KS, Kostopoulos ChC, Stamatelopoulos SF. Ascorbic acid does not improve endothelium-dependent flow-mediated dilatation of the brachial artery in patients with Raynaud's phenomenon secondary to systemic sclerosis. Int J Vitam Nutr Res 2003; 73: 3-7.

15. Cracowski JL, Girolet S, Imbert B, Seinturier C, Stanke-Labesque F, Bessard J, et al. Effects of short-term treatment with vitamin $\mathrm{E}$ in systemic sclerosis: a double blind, randomized, controlled clinical trial of effi- cacy based on urinary isoprostane measurement. Free Radic Biol Med 2005; 38: 98-103.

16. Denton CP, Bunce TD, Dorado MB, Roberts Z, Wilson $\mathrm{H}$, Howell K, et al. Probucol improves symptoms and reduces lipoprotein oxidation susceptibility in patients with Raynaud's phenomenon. Rheumatology (Oxford) 1999; 38: 309-15.

17. Herrick AL, Hollis S, Schofield D, Rieley F, Blann A, Griffin K, et al. A double-blind placebo-controlled trial of antioxidant therapy in limited cutaneous systemic sclerosis. Clin Exp Rheumatol 2000; 18: 349-56.

18. Vignais PV. The superoxide-generating NADPH oxidase: structural aspects and activation mechanism. Cell Mol Life Sci 2002; 59: 1428-59.

19. Muzaffar S, Shukla N, Angelini GD, Jeremy JY. Hypoxia simultaneously induces the expression of gp91phox and endothelial nitric oxide synthase in the pulmonary artery. Thorax 2005; 60: 305-13.

20. Muzaffar S, Jeremy JY, Angelini GD, Stuart-Smith K, Shukla N. The role of the endothelium and nitric oxide synthases in modulating superoxide formation induced by endotoxin and cytokines in porcine pulmonary arteries. Thorax 2003; 58: 598-604.

21. Neufeld G, Cohen T, Gengrinovitch S, Poltorak, Z. Vascular endothelial growth factor (VEGF) and its receptors. FASEB J 1999; 13: 9-22.

22. Gorin Y, Block K, Hernandez J, Bhandari B, Wagner B, Barnes JL, et al. Nox4 NAD(P)H oxidase mediates hypertrophy and fibronectin expression in the diabetic kidney. J Biol Chem 2005; 280: 39616-26.

23. Muzaffar S, Shukla N, Angelini GD, Jeremy JY. Superoxide "auto-augments" the formation of superoxide through upregulation of NADPH oxidase expression in porcine pulmonary artery endothelial cells: inhibition with iloprost. Eur J Pharmacol 2006; 538: 108-14.

24. Muzaffar S, Shukla N, Bond M, Sala-Newby G, Angelini GD, Newby AC, et al. Acute inhibition of superoxide formation and Rac1 activation by nitric oxide and iloprost in human vascular smooth muscle cells in response to the thromboxane A2 analogue, U46619. Prostaglandins Leukot Essent Fatty Acids 2008; 78: 247-55.

25. Hordijk PL. Regulation of NADPH oxidases: the role of Rac proteins. Circ Res 2006; 98: 453-62.

26. Mulder KM. Role of Ras and MAPKs in TGF beta signaling. Cytokine Growth Fact Rev 2000; 11: 23-35.

27. Sambo P, Jannino L, Candela M, Salvi A, Donini M, Dusi S, et al. Monocytes of patients with systemic sclerosis (scleroderma spontaneously release in vitro increased amounts of superoxide anion. J Invest Dermatol. $1999 ; 112: 78-84$.

28. Sambo P, Baroni SS, Luchetti M, Paroncini P, Dusi S, Orlandini $\mathrm{G}$, et al. Oxidative stress in scleroderma: maintenance of scleroderma fibroblast phenotype by the constitutive up-regulation of reactive oxygen species generation through the NADPH oxidase complex pathway. Arthritis Rheum 2001; 44: 2653-64.

29. Svegliati S, Cancello R, Sambo P, Luchetti M, Paroncini $\mathrm{P}$, Orlandini G, et al. Platelet-derived growth factor and reactive oxygen species (ROS) regulate Ras protein levels in primary human fibroblasts via ERK1/2. 
Amplification of ROS and Ras in systemic sclerosis fibroblasts. J Biol Chem 2005; 280: 36474-82.

30. Miyazaki H, Matsuoka H, Cooke JP, Usui M, Ueda S, Okuda S, et al. Endogenous nitric oxide synthase inhibitor: a novel marker of atherosclerosis. Circulation 1999; 99: 1141-6.

31. Dooley A, Gao B, Bradley N, Abraham DJ, Black CM, Jacobs M, et al. Abnormal nitric oxide metabolism in systemic sclerosis: increased levels of nitrated proteins and asymmetric dimethylarginine. Rheumatology (Oxford) 2006; 45: 676-84.

32. Wojciak-Stothard B, Torondel B, Zhao L, Renné T, Leiper JM. Modulation of Rac1 activity by ADMA/ DDAH regulates pulmonary endothelial barrier function. Mol Biol Cell 2009; 20: 33-42.

33. Surdacki A, Martens-Lobenhoffer J, Wloch A, Marewicz E, Rakowski T, Wieczorek-Surdacka E, et al. Elevated plasma asymmetric dimethyl-L-arginine levels are linked to endothelial progenitor cell depletion and carotid atherosclerosis in rheumatoid arthritis. Arthritis Rheum 2007; 56: 809-19.

34. Jacobi J, Sydow K, von Degenfeld G, Zhang Y, Dayoub H, Wang B, et al. Overexpression of dimethylarginine dimethylaminohydrolase reduces tissue asymmetric dimethylarginine levels and enhances angiogenesis. Circulation 2005; 111: 1431-8.

35. Veresh Z, Racz A, Lotz G, Koller A. ADMA impairs nitric oxide-mediated arteriolar function due to increased superoxide production by angiotensin IINAD(P)H oxidase pathway. Hypertension 2008; 52: 960-6.

36. Leiper J, Murray-Rust J, McDonald N, Vallance P. Snitrosylation of dimethylarginine dimethylaminohydrolase regulates enzyme activity: further interactions between nitric oxide synthase and dimethylarginine dimethylaminohydrolase. Proc Natl Acad Sci USA 2002; 99: 13527-32.

37. Jiang JL, Li YJ, Deng HW, Li NS. Probucol preserves endothelial function by reduction of the endogenous nitric oxide synthase inhibitor level. Br J Pharmacol 2002; 135: 1175-82.

38. Morrow JD, Roberts LJ 2nd. The isoprostanes. Current knowledge and directions for future research. Biochem Pharmacol 1996; 51: 1-9.

39. Montuschi P, Barnes PJ, Roberts LI II: Isoprostanes: markers and mediators of oxidative stress. FASEB J 2004; 18: 1791-800.

40. Sorescu D, Szocs K, Griendling KK. NAD(P)H oxidases and their relevance to atherosclerosis. Trend Cardiovasc Med 2001; 11: 124-31.

41. White RP, Heaton JA, Denton IC. Pharmacologic comparison of prostaglandin $\mathrm{F} 2 \alpha$, serotonin and norepinephrine on cerebrovascular tone of monkey. Eur J Pharmacol 1971; 15: 300-9.

42. Takahashi K, Nammour TM, Fukunaga M, Ebert J, Morrow JD, Roberts LJII, et al. Glomerular actions of a free radical-generated novel prostaglandin, 8-epiprostaglandin F2 in the rat. Evidence for interaction with thromboxane A2 receptors. J Clin Invest 1992; 90: 136-41.
43. Yura T, Fukunaga M, Khan R, Nassar GN, Badr KF, Montero A. Free-radical-generated F2-isoprostane stimulates cell proliferation and endothelin-1 expression on endothelial cells. Kidney Int 1999; 56: 471-8.

44. Kunapuli P, Lawson JA, Rokach J, FitzGerald GA. Functional characterization of the ocular prostaglandin F2 $\left(\mathrm{PGF}_{2}\right)$ receptor. Activation by the isoprostane, 12iso-PGF ${ }_{2}$. J Biol Chem 1997; 272: 27147-54.

45. Benndorf RA, Schwedhelm E, Gnann A, Taheri R, Kom G, Didié M, et al. Isoprostanes inhibit vascular endothelial growth factor-induced endothelial cell migration, tube formation, and cardiac vessel sprouting in vitro, as well as angiogenesis in vivo via activation of the thromboxane $\mathrm{A}(2)$ receptor: a potential link between oxidative stress and impaired angiogenesis. Circ Res 2008; 103: 1037-46.

46. Stein CM, Tanner SB, Awad JA, Roberts LJ 2nd, Morrow JD. Evidence of free radical-mediated injury (isoprostane overproduction) in scleroderma. Arthritis Rheum 1996; 39: 1146-50.

47. Ogawa F, Shimizu K, Muroi E, Hara T, Hasegawa M, Takehara K, et al. Serum levels of 8-isoprostane, a marker of oxidative stress, are elevated in patients with systemic sclerosis. Rheumatology (Oxford) 2006; 45: 815-8.

48. Montuschi P, Ciabattoni G, Paredi P, Pantelidis P, du Bois RM, Kharitonov SA, et al. 8-Isoprostane as a biomarker of oxidative stress in interstitial lung diseases. Am J Respir Crit Care Med 1998; 158: 1524-7.

49. Volpe A, Biasi D, Caramaschi P, Mantovani W, Bambara LM, Canestrini S, et al. Levels of F2-isoprostanes in systemic sclerosis: correlation with clinical features. Rheumatology (Oxford) 2006; 45: 314-20.

50. Cracowski JL, Marpeau C, Carpentier PH, Imbert B, Hunt M, Stanke-Labesque F, et al. Enhanced in vivo lipid peroxidation in scleroderma spectrum disorders. Arthritis Rheum 2001; 44: 1143-8.

51. Cracowski JL, Kom GD, Salvat-Melis M, Renversez JC, McCord G, Boignard A, et al. Postocclusive reactive hyperemia inversely correlates with urinary 15F2t-isoprostane levels in systemic sclerosis. Free Radic Biol Med 2006; 40: 1732-7.

52. Fantone JC, Kinnes DA. Prostaglandin E1 and prostaglandin $\mathrm{I} 2$ modulation of superoxide production by human neutrophils. Biochem Biophys Res Commun 1983; 113: 506-12.

53. Simpson PJ, Mickelson J, Fantone JC, Gallagher KP, Lucchesi BR. Iloprost inhibits neutrophil function in vitro and in vivo and limits experimental infarct size in canine heart. Circ Res 1987; 60: 666-73.

54. Kiris I, Tekin I, Yilmaz N, Sutcu R, Karahan N, Ocal A. Iloprost downregulates expression of adhesion molecules and reduces renal injury induced by abdominal aortic ischemia-reperfusion. Ann Vasc Surg 2009; 23: 212-23.

55. Bursch W, Taper HS, Somer MP, Meyer S, Putz B, Schulte-Hermann R. Histochemical and biochemical studies on the effect of the prostacyclin derivative Iloprost on CCl4-induced lipid peroxidation in rat liver and its significance for hepatoprotection. Hepatology 1989; 9: $830-8$. 
56. Yu AL, Fuchshofer R, Kampik A, Welge-Lüssen U. Effects of oxidative stress in trabecular meshwork cells are reduced by prostaglandin analogues. Invest Ophthalmol Vis Sci 2008; 49: 4872-80.

57. Balbir-Gurman A, Braun-Moscovici Y, Livshitz V, Schapira D, Markovits D, Rozin A, et al. Antioxidant status after Iloprost treatment in patients with Raynaud's phenomenon secondary to systemic sclerosis. Clin Rheumatol 2007; 26: 1517-21.

58. Volpe A, Biasi D, Caramaschi P, Bambara LM, Carletto A, Degan M, et al. Iloprost infusion does not reduce oxidative stress in systemic sclerosis. Rheumatol Int 2008; 28: 335-7.

59. Erre GL, De Muro P, Dellacà P, Fenu P, Cherchi GM, Faedda R, et al. Iloprost therapy acutely decreases oxidative stress in patients affected by systemic sclerosis. Clin Exp Rheumatol 2008; 26: 1095-8.

60. Robbins IM, Morrow JD, Christman BW. Oxidant stress but not thromboxane decreases with epoprostenol therapy. Free Radic Biol Med 2005; 38: 568-74.

61. Dedeoglu BD, Aytac E, Suzer O, Balci H, Uzun H, Seymen P, et al. Donor heart preservation with Iloprost supplemented St. Thomas Hospital cardioplegic solution in isolated rat hearts. Prostaglandins Leukot Essent Fatty Acids 2008; 78: 415-21.

62. Ferrari R, Cargnoni A, Curello S, Boffa GM, Ceconi C. Effects of Iloprost (ZK 36374) on glutathione status during ischaemia and reperfusion of rabbit isolated hearts. Br J Pharmacol 1989; 98: 678-84.

63. Schrör K, Ohlendorf R, Darius H. Beneficial effect of a new carbacyclin derivative, ZK 36374, in acute myocardial ischaemia. J Pharmacol Exp Ther 1981; 219: 243-9.

64. Thiemermann C, Steinhagen-thiessen E, Schror K. Inhibition of oxygen-centered free radical formation by the stable prostacyclin-mimetic Iloprost (ZK 36374) in acute myocardial ischaemia. J Cardiovasc Pharmacol 1984; 6: 365-66.

65. Blardi P, de Lalla A, Pieragalli D, De Franco V, Meini S, Ceccatelli L, et al. Effect of Iloprost on plasma asymmetric dimethylarginine and plasma and platelet serotonin in patients with peripheral arterial occlusive disease. Prostaglandins Other Lipid Mediat 2006; 80: 175-82.

66. Coleman RA, Kennedy I, Humphrey PPA. Prostanoids and their receptors. In: Emmett JC, ed. Comprehensive Medicinal Chemistry Vol. 3: Membranes and Receptors. Oxford, UK: Pergamon Press; 1990: 643-714.

67. Grant SM, Goa KL. Iloprost. A review of its pharmacodynamic and pharmacokinetic properties, and therapeutic potential in peripheral vascular disease, myocardial ischaemia and extracorporeal circulation procedures. Drugs 1992; 43: 889-924.

68. Valko M, Leibfritz D, Moncol J, Cronin MT, Mazur M, Telser J. Free radicals and antioxidants in normal physiological functions and human disease. Int J Biochem Cell Biol 2007; 39: 44-84.

69. Nakano H, Monden M, Umeshita K, Murata M, Miyoshi H, Kanai T. Protective effects of prostaglandin I2 analogues on superoxide-induced hepatocyte injury. Ann N Y Acad Sci 1994; 723: 447-50.

70. Cracowski JL, Carpentier PH, Imbert B, Cachot S, Stanke- Labesque F. Bessard J, et al. Increased urinary F2-isoprostanes in systemic sclerosis but not in primary Raynaud's phenomenon: effect of a cold exposure. Arthritis Rheum 2002; 46: 1319-23.

71. Juranek I, Bezek S. Controversy of free radical hypothesis: Reactive oxygen species-Cause or consequence of tissue injury? Gen Physiol Biophys 2005; 24: 263-78.

72. Muzaffar S, Shukla N, Angelini GD, Jeremy JY. Superoxide auto-augments superoxide formation and upregulates gp91(phox) expression in porcine pulmonary artery endothelial cells: inhibition by Iloprost. Eur J Pharmacol 2006; 538:108-14.

73. Muzaffar S, Shukla N, Lobo C, Angelini GD, Jeremy JY. Iloprost inhibits superoxide formation and gp91phox expression induced by the thromboxane A2 analogue U46619, 8-isoprostane F2alpha, prostaglandin F2alpha, cytokines and endotoxin in the pig pulmonary artery. Br J Pharmacol 2004; 141: 488-96.

74. Stratton R, Rajkumar V, Ponticos M, Nichols B, Shiwen $\mathrm{X}$, Black CM, et al. Prostacyclin derivatives prevent the fibrotic response to TGF-beta by inhibiting the Ras/MEK/ERK pathway. FASEB J 2002; 16: 1949-51.

75. Stratton R, Shiwen X, Martini G, Holmes A, Leask A, Haberberger T, et al. Iloprost suppresses connective tissue growth factor production in fibroblasts and in the skin of scleroderma patients. J Clin Invest 2001; 108: 241-50. 